\title{
Ledentsov society: to study of the issue
}

\author{
Andrey Kuzmichev \\ full professor at Bauman University, Moscow
}

\begin{abstract}
Subject. Ledentsov Society - Russia's first private science foundation, combining the interests of business, science and society.

Research hypotheses:

The first - at the beginning of the twentieth century in Russia, traditionally gravitating to the European tradition, public organizations were created aimed at the connection of science and business, one of them was the Ledentsov Society;

The second is how the Ledentsov Society formed a new entrepreneurial ecosystem in Russia at the beginning of the 20th century;

Third - one of the most important results of the activity of the Ledentsov Society was the support of the scientific school of production organization at the Imperial Moscow Technical School.

The topic of creating private scientific foundations of the early twentieth century is mainly related to the study of foreign experience. This article attempts to present a different point of view representing Russian researchers.

Methodology. Narrative, comparative, and historical research methods are used.

Results. As a result of the study, it was shown that in Russia at the beginning of the twentieth century, the creation of the Ledentsov Society became an important element of the new entrepreneurial ecosystem.

Conclusions. The Ledentsov Society is closely connected with the creation of a new scientific school for the organization of production at IMTU. $\mathrm{N}$. Czarnowski is not only the creator of a scientific school, but also the author of the world's first production organization textbook.
\end{abstract}

Keywords: Ledentsov Society, the world's first production organization textbook, Nikolai Czarnowski, scientific school IMTU.

\section{Introduction}

Modern Russian society, in contrast to the society of the USSR, comprehends new terms associated with a radical reorganization of the entire way of social and economic life. Changes in science, both fundamental and applied, are determined not only with the reforms of the Russian Academy of Sciences and the university community. Private and scientific funds become a new and important element, which makes a link between science and business. Presenting the "Forbes First Russian Philanthropist Rating" (2019), Olga Pavlova notes that the rating does not claim to be comprehensive and emphasizes that some funds that have emerged in recent decades are closed. Pavlova refers to Elizabeth Schimpfössl's study, "Rich Russians: From the Oligarchs to the Bourgeoisie" (2018), where philanthropy is 
addressed in a chapter. "The author claims," writes Pavlova, that for wealthy people (especially in the first generation), charity is important to justify the legitimacy of their wealth, but at the same time it helps them to find new interests and tasks. Therefore, large businessmen are engaged in collecting, opening museums and galleries, they support important cultural institutions" [1].

Nevertheless, the role of business in financing the science is extremely small: for example, Professor R.M. Melnikov believes that in modern Russia, in contrast to foreign practice, "the main source of financing the corporate research and development works are the state funds, but not companies' equity capital" [2].

Developing the first hypothesis, one should not, that at the turn of the past centuries the situation with the support of science by the business community in Russia was different: for example, S.M. Bastrakova believes that private donations to science were made by representatives of the business world elite of Russia (including P.I. Gubonin, P.G. von Dervies, K.F. von Meck, I.P. and N.P. Malyutin, N. I. Naydenov, I. F. Bazilevsky, M. S. Sidorov, A. M. and I. M. Sibiryakov, K. T. Soldatenkov; members of the family business of Alekseev, Bazunov, Guchkov, Morozov, Nobel, Paskhalov, Ryabushinsky , Khludov, Shelaputin). Not only new higher education institutions, departments, laboratories, clinics and observatories were created with their support. They acted as sponsors of science, as S.M. Bastrakova considers, even leading scientific societies such as the Russian Geographical Society and Russian Physico-Chemical Society in St. Petersburg or the Society of Naturalists and the Society of Natural History, Anthropology and Ethnography in Moscow, which were developed only due to social assistance and the support of philanthropists [3].

We suppose that this was a global trend. A.N. Blinov, who studied the history of this issue, considers that the appearance of private organizations, which are more similar to modern scientific foundations, dates back to the turn of the 19th and 20th centuries. As examples, he considers the Alexander von Humboldt Foundation (Alexander von HumboldtStiftung, 1860); The Carl Zeiss Foundation (Carl Zeiss Stiftung 1889), and other organizations and writes that they received the greatest development in the United States, where more than one hundred of different charitable foundations were created in the 1900s. He emphasizes that in such foundations as the Russell Sage Foundation, the Carnegie Corporation and the Rockefeller Foundation, the concept of a grant appeared and was applied as a special mechanism for financing the researches [4].

The second hypothesis is devoted to the Ledentsov society, which is practically not known to foreign scientists [5]. But also in Russia, only three works are devoted to the study of the society [6]. Although the personality of H.S. Ledentsov became known in the last decade of the existence of the USSR [7]. In post-Soviet Russia, interest to Khristofor Semenovich Ledentsov increased and new researchers appeared. In Vologda, being his native town, LEDENTSOV READINGS started from the beginning of 2000 [8]. In the second decade of the twenty-first century, several books about Ledentsov were published [9].

Why was the Ledentsov Society the first scientific foundation in Russia? First of all, at the turn of the past centuries, Ledentsov, after he moved from Vologda to Moscow, kept company with representatives of leading scientific and public organizations, and it is reflected in the abovementioned studies. Secondly, let us make the assumption that in the process of society creation, the interests of both leading universities and the best representatives of the business world of Moscow, being the centre of national entrepreneurship of Russia, were taken into account. So, on May 17, 1909, at the first general meeting, Semen Andreevich Fedorov, Honoured Professor of the Imperial Moscow Technical School (The Chairman), Nikolai Alekseevich Umov, Honoured Professor of the Imperial Moscow University (Deputy Chairman), Nikolai Frantsevich Czarnowski, Inspector of educational workshops of the Imperial Moscow Technical School (Secretary), were elected into the Council of the Society [10]. 
Thirdly, we emphasize the important difference between society and other organizations - the creation and activities of expert commissions to identify people, who are worthy of grants [11]. As it is noted by V.A. Volkov and M.V. Kulikova, the company's council considered the applications for subsidies "democratically and expeditiously": the recipients of the grant chose different reporting forms - a report at a meeting of the council or the annual meeting of the Company, an article in the "Vremennik" or just a written report, after which a decision was made to resume or to terminate the funding [12]. But for now, the question remains open - how exactly the individuals who received the grants were determined.

In the fourth place, in the 1910, the "Vremennik" of the Society for Assisting the Successes of Experimental Sciences and Their Practical Applications named after H.S. Ledentsov, where all official information was published both about the work of the company itself and about grants. As an example, in the first year of the company's work various amounts were paid: for example, M.P. Vinogradov was paid 200 roubles, V.A. Shevelin was paid 300 roubles, and N.E. Zhukovsky was paid 2000 roubles [13, inventory 1, ed. 13, L. 119]. By the way, among the nonrepayable subsidies granted in 1909/1910 there are familiar surnames: for example, K. Tsiolkovsky was given 400 roubles, A. Chichibabin - was paid 100 roubles, I.A. Averin - was paid 500 roubles. The total paid amount was 6,728 roubles [13, inventory 1, unit 13, L. 122]. It should be noted that in 1909/1910 only to "adapt existing scientific and auxiliary institutions", most likely, we are talking about equipment for laboratories, the society granted: "To Professor I.P. Pavlov - 1000 roubles, to Professor N.E. Zhukovsky -5000 roubles, to Professor V.I. Grinevetsky -800 roubles". [13, inventory 1, unit 13, L. 124].

At the fifth place, and this is extremely important, information about applications in the style of perpetuum mobile was printed in "Vremennik": for example, it was proposed to create an iron ball being an aircraft and at the same time - a hydraulic press; hydroski - to save the drowning; a signal device attached to the bather's belt and used to locate this bather after the latter has drowned; pneumatic anti-flood shutters; a universal type bed - for all ages of life and therefore serving a person throughout his life; "A screw-twisted metermocraft driven by a petrolpet" - it is the name of the aircraft [14].

The dissolution of the Society in 1918 did not simply mean the cessation of the activities of the first private foundation in Russia: the scientific library of the society and the company's awards - medals and, no less important, respect from scientists and public exposed persons in Russia and all over the world, were abandoned.

The Ledentsov society created the foundation for the appearance in Russia of not only new scientific organizations, but also allowed many scientists to make significant discoveries, including those which are of world significance [15]. Amongst them, Nikolai Frantsevich Czarnowski (1868-1938) [16], whose main work "Organization of Industrial Enterprises for the Processing of Metals" $(1911,1915,1919)$ appeared first in the Bulletin of the Polytechnic Society in 1910-1911 [17]. The training course on the organization of production began to be taught at IMTU since 1904, but Professor S.G. Falco holds the view that it was N.F. Czarnowski who developed the course of lectures [18].

Let us supplement the professor's opinion with the information that it was the Council of the Ledentsov Society, which included "among his tasks, the familiarization with the organization of existing institutions that fully or partially pursue tasks that are similar to or in contact with the Society tasks," sent N.F. Czarnowski abroad as a representative of the Society to international forums, and also in order to attend the international exhibition in Brussels, the Polytechnicum in Aachen, to get acquainted with the organization of the Berlin Patentamt, the patent office of Klostermann in Zurich, and the Deutches Museum in Munich. "Together with these instructions, the Council asked N.F. Czarnowski, as noted in the decision of the Council, to submit a report about his trip and provided him with a subsidy of 300 roubles" [19]. 
In the "Report on a business trip abroad in the summer of 1910, the Secretary of the Society N.F. Czarnowski's organization is represented not only by the above organizations in fact, the researcher significantly exceeded the task: he, in particular, visited the Sack engineering plants near Düsseldorf, L. Loewe in Berlin, AFG in Berlin, Broun et Bovery in Baden (Switzerland), H. Lanz and factory of Benz in Manigheim. "The main interest for me during visits to these factories was to get acquainted with new and constructive types and, in parallel, to get acquainted with the executive side of building these types, because with methods and means of processing parts and assembling machines, as well as with the general structure, equipment and organization of work in workshops," writes Czarnowski. He also makes an important clarification that "with the prevailing type of everywhere - mass production", there is a proliferation and development of automatic machines for the production of any specific parts. As an example, Czarnowski indicates machines for processing pistons of automobile engines at the Benz factory [20].

The current study, if we describe the results, confirmed the hypotheses put forward: indeed, in Russia, at the beginning of the twentieth century, the creation of the Ledentsov Society, which brought together representatives of science, education and society, became an important element of the new entrepreneurial ecosystem. Moreover, the practice of the Ledentsov Society can be as an example for modern scientific foundations.

The findings of the study confirm also the fact that it was the Ledentsov Society that influenced the creation of a new scientific school for the organization of production at IMTU. Thanks to visiting foreign enterprises, and based on own experience (he held senior positions at the Mytishchi and Sormovsky factories), N.F. Czarnowski managed to write the world's first production organization textbook.

\section{References}

1. Olga Pavlova, April 19, 2019, The 20 best charitable foundations of Russia's richest businessmen. The first rating of Russian Forbes philanthropists // https: //www.forbes.ru/milliardery-photogallery/200-bogateyshih-rossiyan-2019375027-20luchshih-blagotvoritelnyh-fondov? Photo = 1 (accessed May.15.2019).

2. Melnikov R.M. Changes in approaches to financing scientific and innovative programs and projects in modern world practice // Financial analytics: problems and solutions. 2016. No. 29 (311). P. 8.

3. Bastrakova M.S. Philanthropic support of science in Russia in the second half of the 19th century // QUESTIONS OF HISTORY OF NATURAL SCIENCE AND TECHNOLOGY, Volume: 33, No. 1 Year: 2012, PP. 49, 56.

4. Blinov A.N. From the history of creation of national scientific funds // Bulletin of The Russian Humanitarian Scientific Fund, No. 1 (70), 2013, PP. 258-259.

5. Alexander Vucinich in the book Science in Russian Culture, 1861-1917. By Stanford: Stanford University Press, 1970, P. 366), writes about various societies in the Russian Empire, including Ledentsovsky. Professor Loren R. Graham in the book "Science in Russia and the Soviet Union: A short history" / Loren R. Graham. - Cambridge: Cambridge University press, 1993, P. 207) describing the fate of the physicist P.N. Lebedev, mentioned at a glance the Ledentsov Society and the University of Shanyavsky. Professor Daniel P. Todes in his book "Ivan Pavlov: A Russian Life in Science" (Oxford University Press; $1^{\text {st }}$ edition (November 12, 2014), P. 305), describes the activities of the great scientist Ivan Pavlov. He writes that Pavlov made a contact with the Ledentsov Society, calling it "a new phenomenon in the life of Russia: a scientific society fully supported by private foundations that received grants through a non-governmental process" and emphasizes that it was created "in March 1909, by the will of a Moscow merchant with the capital of two million roubles» by two state institutions - Moscow 
University and Imperial Moscow Technical School. Professor David E. Lewis, in The Wolff-Kishner Reduction and Related Reactions ( $1^{\text {st }}$ Edition, Imprint: Elsevier, 19th July 2019, PP. 23-24), writes that the Society was founded in 1909 by the will of the philanthropist Christopher Semenovich Ledentsov. In his opinion, the amount "bequeathed by Ledentsov was actually more than the bequest of Alfred Nobel granted to establish the Nobel Prizes, but these funds were confiscated by the Soviet government immediately after the revolution, so the Ledentsov Prizes could never compete with the Nobel Prizes".

6. Morozova, S.G. Society for Assisting the Successes of Experimental Sciences of Kh. S. Ledentsov: his contribution to the scientific and technological progress of Russia - M.: B. and., 1993. - 54 p.; Gaysinskaya L.I. Documentary materials of the Society for Assisting the Successes of Experimental Sciences and Their Practical Applications named after H.S. Ledentsov // Historical archive. - 1995. - No. 5. - P. 110-139; Kuzmichev A.D. Ledentsov 's Society, N.F. Czarnowski and the inventors // Second Czarnowski Readings. Collection of works. Materials of the II international scientific conference on the organization of production. Moscow, December 7 - 8, 2012 - M.: NP “Association of Controllers", 2013, SS. 64-69.

7. Karatygina T.F. Library of the Society for Assisting the Successes of Experimental Sciences and Their Practical Applications named after H.S. Ledentsov // Scientific and technical libraries of the USSR. - 1979. - No. 6. - S. 25-28; Rybnikov V. Name on the obelisk // Red North. - 1985. - July 24, 26; Rybnikov V. Incognito from Vologda // Inventor and rationalizer. - 1987. - No. 9. - S. 38-41.

8. Volkov V.A., M.V. Kulikova Khristofor Semenovich Ledentsov and his Society // Nature. - 1991. - No. 2. - P. 125-128; Antsupova G. Ledetsovskoe Society // Man and Labour. - No. 3. - P. 125-127; Vtorov O.A. Personal Honorary Citizen of Russia // IVF. 2000. - No. 8. - P. 134-143; Lishevsky V.P. Patron of Science // Bulletin of the Russian Academy of Sciences. - 2000. - T. 70 (No. 1). - P. 60-62; Zavyalova O.N. To the question of studying the activity of $\mathrm{Kh}$. S. Ledentsov and "Society for assisting the successes of experimental sciences and their practical applications" // Lacency readings. Business. The Science. Education - materials of the International Scientific and Practical Conference, Vologda, April 22, 2009, Publisher: Non-governmental educational institution of higher professional education Vologda Institute of Business (Vologda), 2009, PP. 50-58; Morozova S.G. Friends of humanity, or Two million gold in Russian science // “CHEMISTRY AND LIFE” No. 4, 2013 / https: //hij.ru/read/issues/2013/april/2536/ (accessed January 7, 2018).

9. Sazonov G.A. "Cannot be measured by the general "arshin"...": the tale of the great Russian philanthropist Christopher Ledentsov. - Vologda: Publisher of ANO "Intelinform", 2012. - 224 p.; Bochkov A.S. Khristofor Semenovich Ledentsov - thinker and philanthropist [Text] / A. S. Bochkov. - Moscow: Luch, 2013. -- 396 p.; Bochkov A.S. Vologda non-possessor Ledentsov Khristofor Semenovich. Imperial Russian Historical Society - Moscow: Cimmerian Centre, 2014. -- 502 P.

10. "Vremennik" of the Society for Assisting the Successes of Experimental Sciences and Their Practical Applications named after H.S. Ledentsov (the life of the Society for 1909) M., 1910, Vol. 1 and 2, P. 15. We would like to mark that S. G. Morozova writes that the society included following titular members: N. D. Zelinsky and V. I. Vernadsky, P. K. Khudyakov and S. A. Chaplygin, A.E. Chichibabin and L.A. Chugaev, A.M. Bochvar and V.V. Zvorykin, D.N. Pryanishnikov and others. N.E. Zhukovsky, I.I. Mechnikov, and K.A. Timiryazev were elected as honorary members of the Society. By 1917, the Society united 290 people already, amongst them were the influential members of the society - S. N. Tretyakov, D. P. Ryabushinsky, N. D. and P. A. Morozov, V. I. Kovalevsky. See more 
details: Morozova S.G. Friends of humanity, or Two million gold in Russian science // CHEMISTRY AND LIFE No. 4, 2013.

11. https: //hij.ru/read/issues/2013/april/2536/ (accessed January 7, 2018).

12. The following expert commissions acted: under the chairmanship of N.E. Zhukovsky for aeronautics; I.A. Kablukov - in chemistry; in electrical engineering - P.N. Lebedev; in chemical technology - P.P. Petrov; on technology of fibrous substances - S.A. Fedorov; in railway, architectural, construction business - A.P. Gavrilenko; on engines of all kinds - V.I. Grinevetsky; for cars, tools, apparatuses - N.F. Czarnowski. - See more details Antsupova G.N. BMSTU through the eyes of a historian. - M., Publishing House of BMSTU, 2000, PP. 110-114

13. Volkov V.A. Kulikova M.V. Khristofor Semenovich Ledentsov and his Society // Nature. - 1991. - No. 2. - PP. 125-128.

http://business.vib.edu.ru/ist_volpr/person/ledentsov/05.htm (accessed 05.06.2019).

14. Central Historical Archive of Moscow

15. "Vremennik" of the Society for Assisting the Successes of Experimental Sciences and Their Practical Applications named after H.S. Ledentsov, M., 1911 Vol. 1., PP.14-15.

16. In particular, these issues are highlighted in the work of Natalia Vedeneeva, The mystery of billions of the "Russian Nobel" // Moskovsky Komsomolets No. 2777 of June 29, 2018 is devoted to these issues.

17. Let us point out the main studies of A.D. Kuzmichev, which are dedicated to Czarnowski: Nikolai Czarnowski: on the $100^{\text {th }}$ anniversary of the world's first management textbook // Materials of the international scientific conference "Economic Reforms in Russia of the XIX - XX Centuries. New approaches, methods and research technologies. M., Moscow State University named after M.V. Lomonosov, November-December 2011 // Writings of the History Department of Moscow State University: Issue. 52. Economic history. Review. Issue 16. M., Publishing House of Moscow State University, 2011, PP. 165-169; Nikolai Czarnowski: milestones of biography // Czarnowski readings. On the occasion of the $100^{\text {th }}$ anniversary of the publication of the world's first management textbook "Organization of Industrial Enterprises for the Processing of Metals". Volume 1. M. Moscow, December 9-10, 2011. M., REC "Controlling and managerial innovation" BMSTU., 2012, PP. 69-77; N.F. Czarnowski and the establishment of scientific management in Russia // Russian Management Journal, Volume 10, No. 3, 2012, PP. 165 176; To the $110^{\text {th }}$ anniversary of the world's first production management course // Problems of Management Theory and Practice, No. 8, 2014, PP. 139-142; Nikolai Czarnowski and the beginning of the twentieth century in Russia: enterprises and their leaders $/ / 8^{\text {th }}$ Czarnowski readings. Proceedings of the VIII All-Russian Scientific Conference on the Organization of Production. FORUM MODERN ENTERPRISE AND THE FUTURE OF RUSSIA. Moscow, December 7-8, 2018 - Moscow: REC “Controlling and Management Innovations", BMSTU; Higher School of Engineering, 2019, PP. 84101; Nikolai Czarnowski - agent of the new time // Economic Strategies, 2019, No. 1, PP. 104-109.

18. Organization of industrial enterprises for metal processing (article) // Bulletin of the Polytechnic Society, under the Imperial Technical School, 1910, No. 1, 2, 5, 1911, No. 4

19. Falko S.G. History of the science about the organization of production. - M., BMSTU, 1988. - P. 13.

20. "Vremennik" of the Society for Assisting the Successes of Experimental Sciences and Their Practical Applications named after H.S. Ledentsov, M., 1910 Vol. 3., PP.6-7.

21. Same, PP. 44-45, 59-60 